\title{
ISLAMIC MICROFINANCE; DEMAND AND CHALLENGES: A CASE STUDY OF DISTRICT GHOTKI, SINDH
}

\author{
Syed Ghazanfar Ahmed* \\ Hafiz Muhammad Ismile**
}

\begin{abstract}
Pakistan is a developing country and it has been showed remarkable development in many areas since its foundation in 1947. However, still some issues have not been handled properly, like poverty, corruption, load shedding, water crises etc. Apart from other issues, poverty is a big issue of the country and it can be observed more or less in every province. In this paper, we have analyzed the ground situation of district Ghotki, through surveys, which is considered last district of Sindh. We tried to find the problems of poor people of district Ghotki, observed their general life style, discussed their issues and inquired about government's role to provide the people with basic necessities of life. In this paper, mainly qualitative method is adopted to reach to best conclusion. However, partially quantitative style could also be observed, especially where concepts of Microfinance are discussed. We realized that around $40 \%$ people of the district need microfinance services and they are ready to welcome Islamic Microfinance banks, because people don't want to opt interest based conventional microfinance services, and secondly, conventional microfinance banks don't have capacity to cover vast area of the district.
\end{abstract}

Keywords: Islamic micro finance, charity, loan, poverty alleviation, qarz-e-hasana, rural areas, district Ghotki

\section{Introduction}

Poverty is a world-wide big dilemma and needs serious attention everywhere. More than eight million people across the world die each year because they don't get basic necessities to survive.(Sachs, 2005) ${ }^{1}$ Countries have created special departments to control and reduce poverty and improve overall living standard of their people. According to Haughton and Khandkar, Poverty arises when people lack key capabilities, and so have insufficient income or schooling, or poor fitness, or lack of confidence, or a sense of helplessness or the absence of the rights, such as liberty of expressing their opinion or lack to power to fight for their rights. (Haughton, Khandkar, 2009) ${ }^{2}$ Thus, poverty is a multidimensional phenomenon and not an easy issue to handle. Our country since its foundation has been facing this issue till to date. In fact, this issue has not been

\footnotetext{
"Syed Ghazanfar Ahmed, Ph.D. Assistant Professor, Dept. of Quran \& Sunnah, University of Karachi.

** Hafiz Muhammad Ismile, Research Scholor, Sheikh Zayed Islamic Centre, University of Karachi.

${ }^{1}$ Sachs, Jaffery D. The End of Poverty, economic possibilities for our time, (New York: The Penguin Press, 2005), pp.3-5

${ }^{2}$ Haughton \& Khandker, Handbook on Poverty and Inequality, (Washington DC. USA: The World Bank, 2009), pp.2-4
} 
addressed by the governments, as it should have been catered. Instead of solving the issue, more focus has been on politicizing it and using it just to gain votes and more popularity among poor.

From the foundation of our country till to date, poverty rate has been, no doubt, decreased but still millions of people are deprived of basic necessities of life. According to a National Assembly Secretariat report presented by Ministry of Planning and Development in the Parliament of Pakistan, more than $30 \%$ People of Pakistan have to live below the poverty limit, which means around 55 million people are desperately poor.(NA Secretariat, 2016) ${ }^{3}$

If the government has not been able to handle the situation properly, it becomes society's responsibility to play their part. The society can do it individually or collectively and no doubt, individuals have been playing their role and Pakistan is one of the top country where highest donations are given away every year (Shazia and Ali, 2018) ${ }^{4}$, but this is has to be done in a systematic way because of very high rate of poverty across the country, that's why it is important that it must be done at huge scale, either by the government or by some big institutions/limited companies. CMFi have been playing their role to reduce the problems of underprivileged people. Although, it is debatable whether they succeeded in their mission or not. In this article, we will be highlighting the position of DG, role of conventional microfinance players there and need and demand of Shariahcompliant microfinance services there.

In this paper, we have focused on District Ghotki and through various surveys and interviews we have elaborated precisely the general living standard of people of Ghotki, their common problems and issues and the level of Government's services in the district. The paper particularly discusses the role of the government, NGOs and conventional microfinance institutions of the area on poverty alleviation and provides sound recommendations about how poverty may be further reduced in the area through Islamic Microfinance.

\section{Microfinance and its Need}

Microfinance is a service provided by conventional microfinance companies to cater the needs of poor people. They allow them to receive small business loans, health loans, marriage loans, education loans etc., generally without collateral, more often, on social and group guaranty. They are also given the opportunity to poor to open the accounts with them, and avail some those facilities which are offered by conventional banks to his clients, but these conventional banks don't facilitate to these poor because of one or other reason.

\footnotetext{
${ }^{3}$ National Assembly of Pakistan, Question Answer Session 34, retrieved from: [http://www.na.gov.pk/uploads/documents/questions/1470057800_189.pdf, p.18

${ }^{4}$ Amjad and Shazia, The journal "Stanford Social Innovation Review" published an article on March 19, 2018 with the title "Philanthropy in Pakistan", written by Shazia Muhammad Amjad and Muhammad Ali. Retrieved from the website: [https://ssir.org/articles/entry/philanthropy_in_pakistan]
} 
As stated above, poverty is a big dilemma and world's big issue, started to address through microfinance in 1970s. Shore bank was the first microfinance and community development bank founded 1974 in Chicago, USA. ${ }^{5}$

Then 1983, Muhammad Younus laid foundation of Grameen Microfinance bank in Bangladesh $^{6}$ and changed the overall concept of microfinance, that's why its founder was honored by noble prize in 2006 (Noble Prize, 2006) ${ }^{7}$. Since 1980, the Grameen has worked tremendously in Bangladesh, focused on women by giving them small business loans on convenient repay schedule of daily 2 tikka or 12 tikka weekly(grameen, n.d.). ${ }^{8}$ By its unique characteristics, the Grameen soon got popular and brought positive change in overall financial status of thousands of people.

\section{Conventional Microfinance Intuitions (CMFis/Banks in Pakistan}

In Pakistan, Microfinance banks have been playing their role since 2000. (sbp, 2006) ${ }^{9}$ First microfinance bank was Khushhali bank, which started its operation in 2001. Then, many other banks started their operations in the country and they have been providing their services till to date across Pakistan. By now [June 2018], following microfinance banks/institutes working in Pakistan: Khushhali Microfinance Bank Limited, First microfinance bank Limited, Telenor Microfinance Bank Limited, Kashf Microfinance Bank Limited, National Rural Support Program (NRSP) Microfinance Bank Ltd., Finca Microfinance Bank Ltd., Sindh Microfinance Bank Ltd.,U Microfinance Bank Ltd. And Advance Pakistan Microfinance Bank Limited.

Khushali bank is the pioneer of microfinance banks in Pakistan and it has more than 150 branches across Pakistan, including Gilgit Baltistan and Azad Kashmir. Similarly, First Microfinance bank, Telenor Bank and Finca Bank have also more than 100 branches across Pakistan. All these banks have been providing their services for last 15-20 years in the country and they have, to some extent, played their role to address the needs of around 4 million(microfinance connect, 2016) ${ }^{10}$ underprivileged people. However, millions of poor have not yet received the services because of their limited outreach and capacity.

\footnotetext{
${ }^{5}$ Cedric Lutzenkirchen, Article "Microfinance in evolution", published by Deutsche Bank Research Marketing, Frankfurt, Germany on September 13, 2012 Retrieved from website: www.esocialsciences.org/Download/Download.asp

${ }^{6}$ Younus, Muhammad, Creating a world without poverty, (New York: Public Affairs, 2007), pp.77-80

${ }^{7}$ Younus, Muhammad, was given noble prize in 2006. Retrieved from the website: https://www.nobelprize.org/nobel_prizes/peace/laureates/2006/

${ }^{8}$ Available at: http://www.grameen.com/method-of-action/. Retrieved on July 5, 2018

${ }^{9}$ Microfinance, history. The state bank of bank of Pakistan presented brief history of Microfinance in Pakistan in $2^{\text {nd }}$ quarterly report of financial year 2006:

http://www.sbp.org.pk/reports/quarterly/fy06/second/microfinance.pdf. Retrieved on Jun25, 2018.

${ }^{10}$ Microfinance, Active members in Pakistan. The website claims that by 2016, there were around 4 million active borrowers using the services of CMFi: Available at: http://www.microfinanceconnect.info/industrynews. Retrieved on 6 July, 2018
} 


\section{Islamic Microfinance}

Conventional Microfinance has been playing its role to provide variety of services to poor. However, it has been debatable whether their services reduced the poverty? Or have the poor managed to solve their problems and improved their overall life style? Pakistan is a Muslim country where more than $90 \%$ Muslims live who consider 'interest' HARAM/unlawful and a major sin. Everyone, whether he is a rich or poor, tries to keep himself away from interest-based financial matters. However, when they don't get opportunity to go with interest free financial deals, they are left with no option but to opt these interest-based services, though with heavy heart. Conventional Microfinance institutions' all services are also based on interest that's why it has never been first choice of people of Pakistan. So, since the foundation of CMFis, the need of Riba-free microfinance services has been felt and there has been high demand of Sharih-based services for underprivileged people.

Furthermore, these CMFis not only charge interest but, unlike, conventional banks their rate of interest have also been very high. Across the world, CMFis charge higher rates of interest on their services ( Sounssi, 2017) ${ }^{11}$, as compare to conventional banks. Normally, their interest rate is $20 \%-34 \%$, which is very high as maximum interest rate of conventional banks is $8 \%-25 \%$. (National Assembly, 2017) ${ }^{12}$.

In this scenario, it is believed that these conventional microfinance banks have very little concern with the poor, and their basic aim is to just run their business and earn maximum profit. They, as per some studies (Rosenberg, 2009) ${ }^{13}$, have not brought any visible change in poor's lifestyle. Instead, they somehow worsen the position of the poor.

So, the need of Shariah compliant Microfinance has been seriously felt, keeping in mind its need, the first Islamic Microfinance bank had started its operation in 1987 in Malysia.(aim, 2018) ${ }^{14}$ Since then, everywhere in the world, Islamic Microfinance began. Some famous Islamic Microfinance providers are:

- Amanah-Ikhtiar Microfinance Bank, Malaysia, NRSP Islamic Microfinance bank, Pakistan, Al-Barkah Microfinance bank, Nigeria, Islamic Microfinance Bank Ltd., Bangladesh,TMSS Islamic Microfinance, Bangladesh, Islamic Rural Bank, Indonesia, Al-Huda Centre of Islamic Banking \& Economics, UAE.

\footnotetext{
${ }^{11}$ National Assembly of Pakistan, Question Answer Session 34, Available at:

[http://www.na.gov.pk/uploads/documents/questions/1470057800_189.pdf.]. Retrieved on July 3, 2018

${ }^{12}$ Rosenberg, Richard, article "Does Microfinance really help Poor People"?

October 2009 on cgap.org. Available at: http://www.cgap.org/blog/does-microcredit-really-help-poor-people. Retrieved on June 28, 2018.

Ben Rogaly, Susan Johnson have also discussed key aspects on the topic in their book: Microfinance and Poverty Reduction, (UK: Oxfam, 1999)

Sundaresan, Suresh has also discussed key aspects of conventional microfinance in his book: Microfinance:

Emerging Trends and Challenges, (UK: Edward Elgar Publishing Limited, 2008)

${ }^{13}$ Available on www.aim.gov.my/introduction.php. Retrieved on June 27, 2018

${ }^{14}$ National Rural Support Program Microfinance Bank. Relevant data available at:

[https://www.nrspbank.com/introduction.php.]. Retrieved on July 1, 2018
} 
These are some prominent Islamic Microfinance banks which have been providing their services in their regions for last ten years and gained reputation in their countries. However, Pakistan is new in in this field and NRSP just started its services two years back from Bhawalpure, but now it is growing rapidly.(NRSP,2018) ${ }^{15}$

\section{Research Method}

This research is based on surveys done in 20 union councils of District Ghotki. A total 400 households were surveyed, with three villages were selected form each union council. 10-12 houses were selected from each village at random for survey. The survey was done during November, 2017 to February, 2018. The objective of survey was to assess general living standard of people of D.Ghotki, and analyze the demand and challenges for Islamic Microfinance institutions (IsMFIs) at D.Ghotki. To assess the standard of people, health facilities and general health condition, educational services and literacy rate, basic infrastructure, and their average income were observed. Variety of Questionnaire had been set for gathering desired information from various part of the community of DG. Furthermore, to obtain exact findings, where required, face-to-face casual interviews were also taken.

\section{General living Standard of people of District Ghotki}

District Ghotki is a part of Sukkur Division, and its last district of Sindh. Its borders link with Sadiqbad(Punjab) from North Sdie and Pannu Aqil from West Side, It has five Taluqa/Tehsil. Ghotki, Khangarh, Mirpur Mathelo, Daharki andUbauro. Its capital is Mirpur Mathelo. There are14 union councils in Taluqa Ghotki, 8 in Mirpur Mathelo, 6 in Dahrki, 8 in Ubauro, and 4 in Khangrah. So, overall there are 40 union councils in Disctrict Ghotki. Estimated population of district Ghotki is 1.64 million as per 2017 cense. (pbs, 2017) ${ }^{16}$

\section{Health Services}

During past five years (2013-2018), health facilities enhanced and infrastructure of hospitals was also improved in District Ghotki. However, still things are not at par and people are not fully satisfied. Most the people (around 40\%) complained of less facilities, as still there is no proper facility of major surgeries, like heart surgery, no proper departments for brain diseases, no proper surgery facilities for displacement/broken bones, no proper dental clinics etc. and without any hesitation these patients are referred to Rahim Yar Khan, Sukkur or Karachi, which is unfair with the patients specially heart and brain patients who need emergency treatment but because of lack of facilities succumb to death. Although, there are some good private hospitals/clinics in Ghotki,

${ }^{15}$ Census, Pakistan, Information as per record of census 2017 provided by Pakistan Bureau of Statistics. Available

${ }^{16}$ Education, Sindh. Retrieved (on $26^{\text {th }}$ June, 2018) statistics of educational institutions in district Ghotki from following website: [http://www.schoolinglog.com/School-College-Systems-By/Primary-School/GovernmentOf-Sindh/Sindh/Ghotki. 
Mirpur Mathelo and Daharki but they are also very few and expensive as well. So, undoubtedly there is a need of enhancement of departments as well as facilities.

Secondly, more hospitals in every Taulqa also need to be built, as now there is 1 hospital for around 75,000 people and international standard is one proper health unit for every 10,000 people. So, this also need to be addressed and at least one more proper complete health unit is required in every Taluqa/Tehsil.

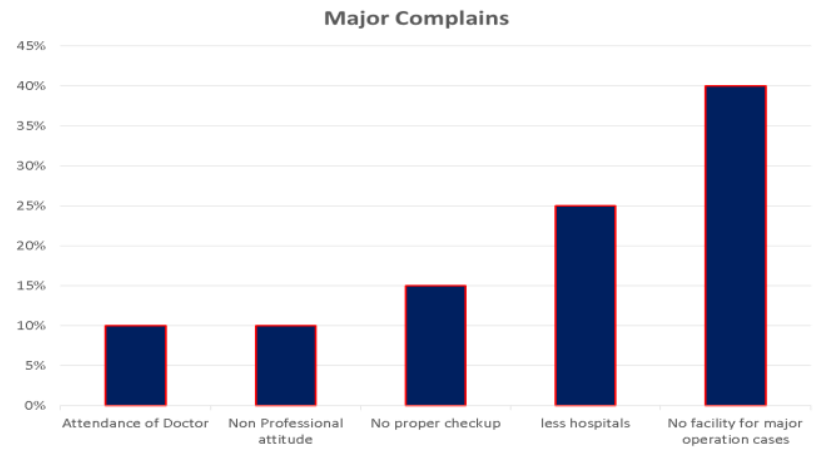

Fig. 1.1 Health issues in district Ghotki

Non-Professional attitude of doctors/staff, absence of duty doctors and improper checkups are also some burning issues which must be addressed. Patients are brought by their relatives sometimes from $10 \mathrm{~km}$ distance in a very difficult manner. As there is no proper ambulance service available in major part of the districts and linked roads are also not up to the mark, we can realize the pain of the villagers/patients how hardly they manage to get to the hospital and if, there, they are badly treated, what would be their feelings? It cannot be imagined, so there is serious need that this issue be properly addressed. The above chart clearly indicates that more than 50\% people did not show their satisfaction with the services they have been receiving from govt. hospitals.

\section{Govt. Educational Services in district Ghotki}

As per the record of Govt. of Sindh, there are 1534 primary schools, 79 middle schools, $35 \mathrm{High} /$ Higher Secondary Schools and 3 degree colleges in district Ghotki. Then, if we analysis gender-wise schools' position, so we learn that there are 984 boys schools, 212 girls schools and 452 combined schools in the region.(Sindh education, 2017) ${ }^{17}$. After survey of district Ghotki, we concluded following points:

${ }^{17}$ BBC, Urdu. A research article published on BBC Urdu website on June $29^{\text {th }}, 2018$. Data retrieved on $30^{\text {th }}$ June, 2018 from the website: https://www.bbc.com/urdu/resources/idt-sh/schools_pakistan. 


\section{Primary Schools}

We found primary schools almost everywhere in the district and the graph 1.3 also clearly indicating this fact. There are more than 1500 primary schools in the district and we consider it a handsome number. However, infrastructure wise, we did not find them satisfactory. In majority of the schools, either there were no toilets or they were not usable. We found hand pump almost in every primary school, although in some schools they were not functional. Electricity was available, but as in this district average schedule of load shedding is around 18 hours, it was necessary that there should have been alternative electric supply (Ups or Solar system) but we could not find any alternative and the students had to sit in hot weather in a very difficult manner.

At primary level, there were no subject specialist and we found one teacher for 1 class who was responsible to teach all subjects of the class. After talking with parents, we realized that the matter of attendance of the teachers has been significantly improved because of strict measures taken by the department of education, Sindh. However, parents were partially satisfied with the level of education and demanded more individual attention for their kids, as majority of them were not literate but dreaming high for their kids. So, they want that their children must learn in a systematic way in schools and the teachers must evaluate that every kid is learning properly, what he is supposed to learn.

\section{Middle and High Schools}

There is an immense difference between the number of primary and high schools. As per our survey, there is dire need of new middle, high and higher secondary schools in the district, as currently there are only 79 middle and 35 high schools for around 2 lac children of the district. Then, there are only 3 degree colleges and there is no university in the whole district and the students have to move to other districts like Khairpur and Sukkur for higher studies.

\section{Literacy Rate}

In our survey, we found more than 50\% illiterate. However, these illiterate people have very dream for their kids and they want them to study as higher as possible. But still because of many factors, more than $40 \%$ children don't go beyond primary. Apart from other factors, poverty and unemployment are major factors. People have no option but to force their small kids to help them in their earnings. Because of no proper employments some consider education waste of time and prefer to teach their kids some basic farming skills, auto mechanical skills etc. That's why the following graph clearly indicates low rate of literacy in the district, especially towards higher studies. 


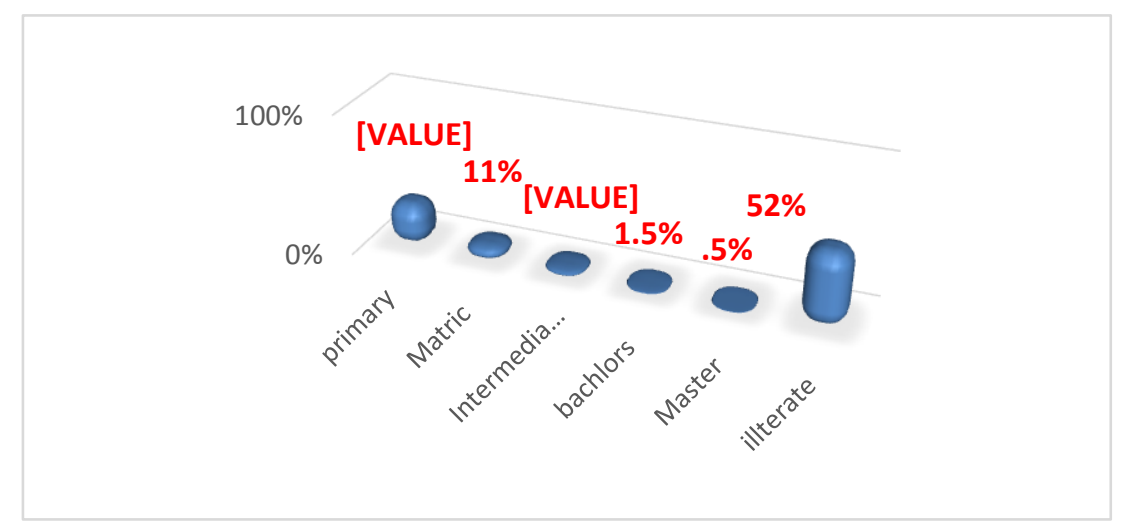

Fig. 1.2 Literacy rate of District Ghotki

\section{Girls Schools}

Pakistan is an Islamic republic state and traditionally people have been avoiding coeducation especially in rural areas. Same thing we found in Ghotki where gender wise school ratio is 70-30. There are around 1000 schools for boys and around 200 schools for girls. In our survey, many parents disclosed that they were willing to send their daughters to middle and high schools, but they could not do so, because of no girls' schools available in the vicinity. Educated women can change the society and fight for their rights in a way better than uneducated women. It is our responsibility to provide our daughters best facilities to get proper education, not only primary, but higher education as well. Hence, more girls middle/high schools must be built as soon as possible for better tomorrow.

As per the report of BBC, in Sindh, educational institutions have got worsen during 201317 and basic facilities of most of the institutions have been reduced because of lack of attention by the Government and not utilizing funds properly for required repair and maintenance work. According to the report, during last five years KPK proved to be on the top for providing basic facilities to schools, then comes Punjab, then Baluchistan, and Sindh is at the bottom. [BBC Urdu, 2018 ${ }^{18}$

\footnotetext{
${ }^{18}$ The interview of Mr. Abid Qamar, Chief spokesman, SBP is available at: https://www.thenews.com.pk/print/50776-sbp-grants-islamic-banking-licence-to-microfinance-bank. Retrieved on July 3, 2018
} 


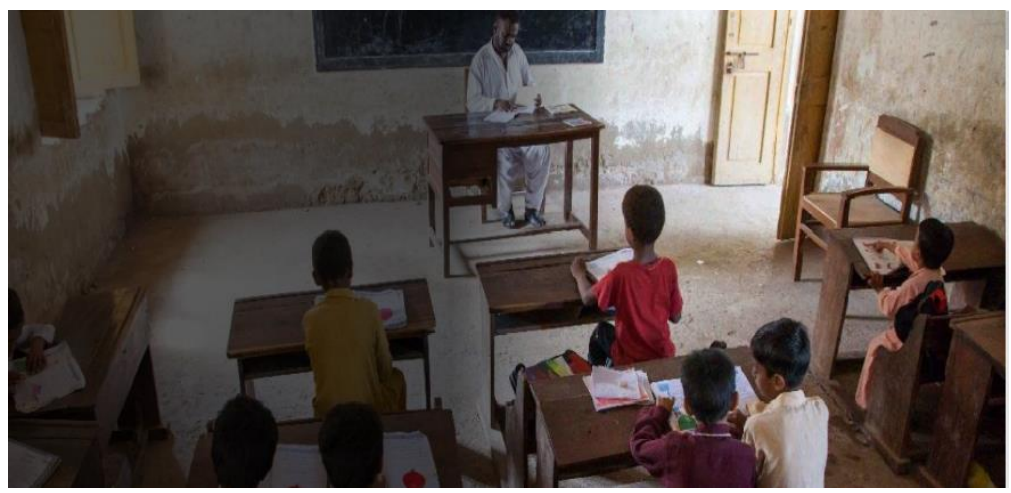

Fig. 1.3 View of a class room in a school of interior Sindh

\section{Basic Infrastructure}

The government is responsible to provide basic infrastructure to people. Water, electricity, natural gas, roads, transport, proper drainage etc. are some basic needs and rights of every citizen of the country. Below are the results of our survey in different parts of DG.

\section{Drinking Water}

Water is most important need of human beings and live stocks. It is a symbol of life and without it, there is no concept of life. Unfortunately, the situation of water is not satisfactory across Pakistan and people are not able to rely on govt. supplied water and they have to buy drinking water, especially in big cities.

In District Ghotki, we, in most of the area, did not find government supplied drinking water facility. However, canals do exist everywhere, which are generally used by the people for their agriculture and for other needs. For drinking, almost every household has hand pump which they arrange on their own. Nevertheless, there are few government hand pumps as well in most of the towns for public use, but they are very few and far from people's reach, so, their utility is limited.

To save money, people don't arrange deep digging for hand pumps and an average depth of the hand pump is around 30-40 feet, which should have been at least 70-80 feet. This is how they are not getting good quality drinking water and, hence, being caught by hepatitis, typhoid, and other diseases caused by using impure water for drinking and cooking.

\section{Electricity}

Electricity is available almost in $70 \%$ area of the district. However, it has little benefit to people because of huge load shedding schedule which is around 18 hours in rural areas, 
and 12-14 hours in urban areas. People generally don't bother to pay the bills and electric company (wapda) has also not been putting their best effort to collect bills from frequent nonpayers. Instead, they have just increased load shedding everywhere, which, we thing is not a solution. Those who can afford, have arranged alternative supplies; Ups, generators and solar panels commonly being used in the district as alternative to govt. supply. Solar panels are most common alternatives used by the people in the district.

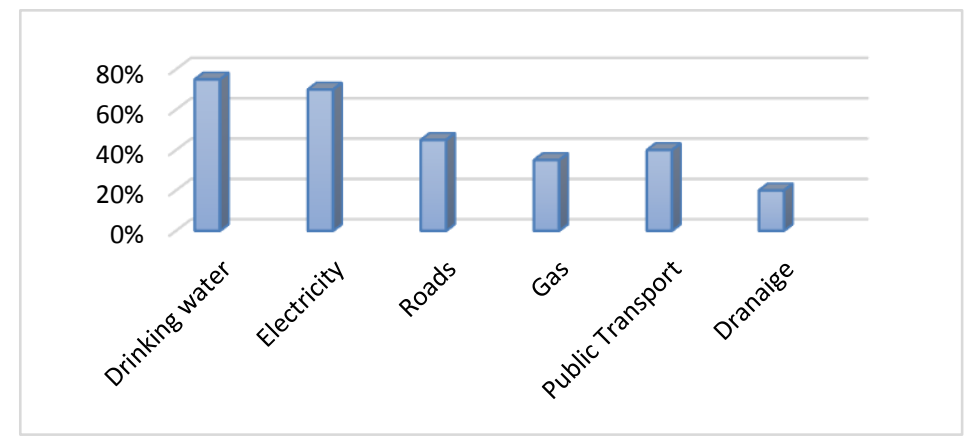

Fig. 1.4 Chart of Basic Facilities in district Ghotki

\section{Natural Gas}

Gas is available in almost $85 \%$ urban areas of all Taluqas. However, more than 50\% rural areas are yet deprived of gas and still people have to use dry woods or gas cylinders for cooking.

\section{Drainage}

It seems that the matter of drainage is not in the priority list of the government at all. Almost the whole district $(80 \%)$ has no proper drainage system. Cities have decades' back drainage system, which has not been repaired or improved for years. On the other hand, there is no drainage system in rural areas at all which, undoubtedly, is leading to various diseases like dengue, malaria, typhoid, cough etc.

\section{Roads}

Roads have been built recently across the district and now $70 \%$ of urban areas' roads are in good condition. However, as you approach to small union councils and to villages, either roads don't exist $(30 \%)$ or their situation is pathetic $(50 \%)$. That's why the villagers who daily has to traveler from villages to city, suffer a lot and a journey that could be done within 15-20 minutes, take 40-50 minutes because of poor roads. 


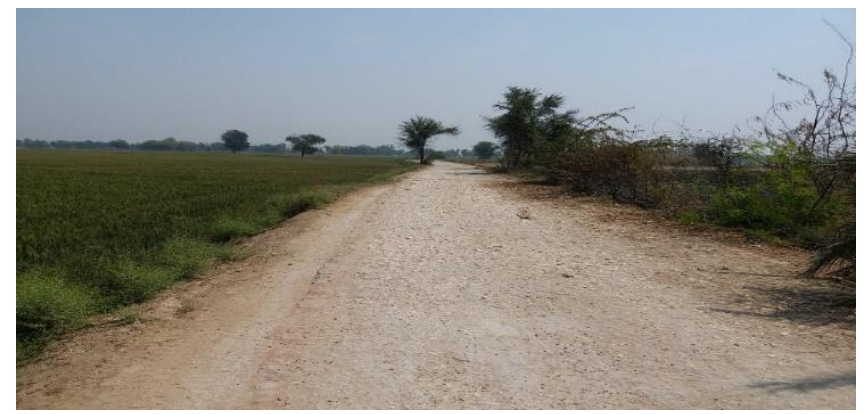

Fig. 1.5 A view of poor road condition in DG

\section{Employment and Average income}

Like other part of the country, people of district Ghotki love Govt. jobs, but there are around $8-10 \%$ people who are lucky enough to get government jobs and they are not on higher side. A decent number of people $(25 \%)$ have been working in private organizations like in FFC, Engro, Mari Gas, Sugar Mills, banks etc. Majority of the people involved somehow in farming related activities (40\%). Rest of the people(25\%) earn through driving local transport, tractor trollies, auto mechanics, fruits and veggies small shops, small milk shops, Kiryana Shops etc.

More than $50 \%$ people's average income is less than 20,000. Around $60 \%$ people's monthly earning is around 10-12,000 and around 25\% earn even less than 10,000. It means around 4 lac people in the district have been dragging their lives and hardly managing their basic necessities.

Around 50\% are hardly managing their expenses and almost every month they need to take some loan to meet their basic necessities of life, as their income is always at low scale, they fail to come out of loan + interest. Consequently, they life day by day gets miserable.

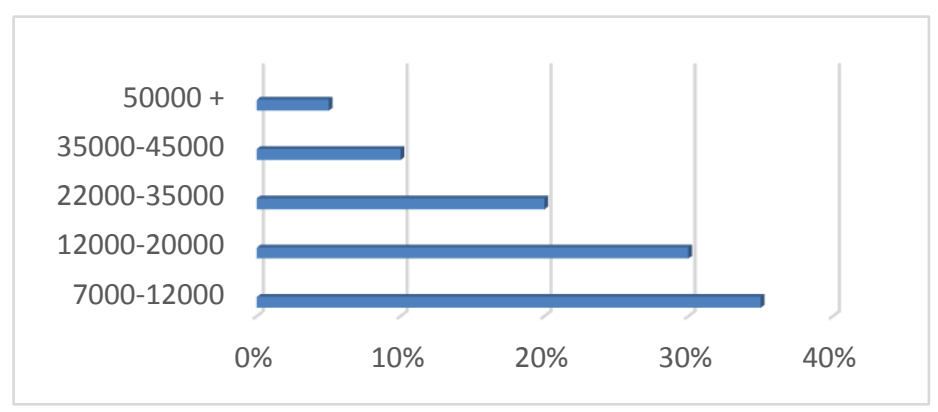

Fig. 1.6 Average Income of people of district Ghotki 
All above surveys show that the life style of people of Ghotki is not satisfactory and the Govt. did make efforts to provide the people with basic facilities but they have partially succeeded in their job and still many areas need to be further improved.

\section{Role of Conventional Microfinance}

As we have discussed above, there is a real scope of Microfinance in the district, different microfinance banks have been capturing the market and providing their services to underprivileged people. We found following microfinance banks in the district:
1. Khushali Microfinance Bank
4. Telenor Microfinance Bank
2. U Microfinance Bank
5. First Microfinance Bank
3. Finca Microfinance Bank.

These institutions have been providing variety of products for more than a decade. However, they have been able to cover around $40 \%$ underprivileged people of the district so far. Secondly, because of high rate of interest on different products, their role in poverty alleviation is very limited.

\section{Demand and Challenges for Islamic Microfinance}

The concept of Islamic Microfinance is not so old and the industry started in its journey in Malaysia in 2010, as stated above. It is at very amateur stage in Pakistan as well and the first Islamic Microfinance bank, NRSP Islamic Microfinance Bank, was given the license by the State of Pakistan in 2015 to run their pilot project ${ }^{19}$ and then in 2016 the bank was allowed to provide all interest free services to poor.

\section{Demand in District Ghotki}

As discussed at length in previous pages, general lifestyle of almost $50 \%$ of people is not satisfactory and around $40 \%$ fall in the category of "poor", whose life is very tough and they constantly need support from some NGOs, Government Poverty Controlling departments or from Microfinance Institutions. There are thousands of people in the district who has to take loan on heavy interest from local money lenders to meet their basic needs.

We have also analyzed the role of Government to facilitate the poor, which is not up to mark at all. The government has been doing one thing and that is disbursing very small amount among selected poor women through "Benazir income Support Card"20 [http://bisp.gov.pk/ ], but that is not enough because of two main reasons; firstly, the amount is very less, only 1500 rupees per month are being disbursed and they are also given lump sum on quarterly basis. Selected poor women get Rs. 4500 through ATM card after every three months. In our survey, people did appreciate government step, but on the same time they complained that the amount is very less and it must be increased.

\footnotetext{
${ }^{19}$ Benazir income support program started in 2008. Data available at: http://bisp.gov.pk/. Retrieved on July 4, 2018

${ }_{20}$ Ibid., bisp.gov.pk/Introduction. Retrieved on July 3, 2018
} 
Secondly in every village, because of one or other reasons, selected poor women are receiving this facility and there are hundreds of poor who had failed to get their names registered with the government 10 years back in 2008 [bisp, 2008] ${ }^{21}$. So despite the fact, they are deserving, they have been receiving nothing. According to them, they had put every effort to get their families' registered but failed.

One more factor is also important and that is use of this card by male member of the families. Initially this card was issued to poor women and the idea was to empower women by directly transferring cash to their accounts, but it has been observed that the smart card is in the control of males because of dominance of man in the district and more illiteracy among women who, being absolutely illiterate, are unable to operate smart cards at ATMs.

So, the bottom line is that "Benazir Income support Program" has limited value and this step has catered the poverty of thousands of people, but on very limited scale and still people is looking for some decent support.

\section{Challenges for Islamic Microfinance Institutions in District Ghotki}

Undoubtedly, there is real need of new microfinance players in the district but the new players at the beginning may also face some challenges. However, these challenges may be handled by any professional institution with little wisdom and home work.

- As discussed above, prominent conventional microfinance players have been doing well in the region. So, initially, Islamic microfinance banks may face tough challenge of establishing themselves and making good reputation in the district.

IMB will have to launch their branches wisely, targeting the areas which have not yet been covered by CMB, especially KhanGarh, Micrpure Mathelo and Obaro because almost all CMBs have focused Ghotki city and Dahrki so far, so it will be better move by IMB to open their branches in rest of their area. As per our survey, rest of the area is also full of potential customers of IMB and they, soon, may establish their reputation in rest of three Taluqas by providing good products and quality services to underprivileged people.

- Before introducing its products, it is important for IMBs to study and understand the culture of people of district Ghotki to avoid any possible failure of their product(s). Every product may not be equally good for people of different background, culture and tribe. Furthermore, products rate should also be competitive but not more than $\mathrm{CMB}$, otherwise IMB may not be able to get good results.

${ }^{21}$ Grameen bank is well-known because of its unprecedented social work in underprivileged communities. Available at: http://www.grameen.com/16-decisions/. Retrieved on July 5, 2018. 


\section{What IsMFi may offer?}

After survey of vast part of the district, we think that following products may be offered by IMB in this district.

- Salam: As per our survey, most hit product of IMB may be SALAM, as major part of the poor live in rural areas and depend on farming. So, if Salam is offered wisely, it will cater agriculture need of the farmers and will be definitely most prominent products of IMBs. So, it should be must have product of all IMBs for this region.

- Qarz-e-Hasanah: Lending Qarza-e-Hasanah is always very difficult, historically, for Islamic banks, and same will go for IMBs. But they should not straight away refuse every needy. It's better to keep this option open for real needy. Small amounts $(10,000-25,000)$ may be lent after strict security and ensuring recovery process within stipulated duration.

- Diminishing Musharkah: This is yet another very good product and can be offered by IMBs in the district, especially for building houses for poor.

- Ijarah and Murabahah: Both of these products may also be offered by IMBs in the region for Motorcycles, tractors, tube wells etc.

- Istisna: It can also very offered, though at limited scale, if someone needs any manufacturing related product to buy. The IMBs may help them by Istisna. However, this product may have least popularity in the region.

- Musharakh and Mudarbah: Like other Islamic Banks, IMBs will also have to be careful about offering these products. Mudarabah can be used by IMBs for opening the accounts of the poor. However, for at least initial 5-8 years they must rely on other products and focus on providing services and maintain good relationship with the clients. After establishing themselves and gaining good reputation and handsome profit, they may think to go for these two products as well.

\section{Findings}

After detailed research, we have reached at following conclusions:

- The Government role to control the poverty is very limited.

- NGOs are performing to some extent but they don't have capacity to cover most part of the district.

- Microfinance Banks are most important player who have been, as compare to Government and NGOs, more professionally addressing the problems of the poor. 
- In our survey, we realize that people are ready to warmly welcome Shariahcompliant products. They are not happy with the services of conventional Microfinance banks, because being Muslims, they do realize that their services are based on "interest", which is strictly prohibited in Islam.

- They stated that as they don't have other option and nobody is caring them for their basic needs. They are bound to go for interest based services. However, they want to get rid of these Riba based services and would be more than happy to welcome Islamic Microfinance banks in the district.

\section{Steps to be taken}

In that scenario, still we can thing that there is a lot of room for Islamic Microfinance banks to establish themselves in the district and offer shariah-compliant products to the community.

Need of creating more awareness among the people about Riba-free services. This is also very important aspect that must be able to clarify the difference between conventional microfinance services and Shariah-Compliant Microfinance services. If, during first year, they fail to make the people understand clear difference between the both, they might not be able to establish themselves in the region. So, it's not the matter of their reputation, but its matter of their survival. Its matter of bringing people to Sharaih-compliant system, saving them from clear unlawful which has been explicitly declared unlawful so many time in Holy Qur'an.

Need of well-trained, dedicated and hard-working staff. As the IMBs will be starting their services in the area, where CMBs working for decade. Hiring of qualified professionals is very important for the success of IMBs, who must be able to guide their clients properly. They should not be able to guide the people about their own products, but one the same time, they must be able to make the people understand how clearly their products are different from CMBs products. The staff must be hard-working, able to visit remote/rural areas to convince the customer to get their products. IMBs cannot run their services sitting in the branches, this is what their staff must realize for the success of their products in this particular region.

There is a need of some welfare work and social-business in the region. CMBs have not been doing any sort of welfare work in the region. To be unique and exclusive and to gain people attention, it will be important for the IMBs to start some welfare works free of cost for general poor public and they must spare some amount for this noble job on regular basis. This is how they can get good reputation within months and people will forget about CMBs. Small need-based social businesses in the villages can also help build up good reputation of CMBs. The same has been adopted by the grameen in Bangladesh 
(Younus, 2007), Amanah Ikhtiar(aim,n.d.) $)^{22}$ in Malaysia and to some extent Akhuwat in Pakistan (akhuwat, 2017) ${ }^{23}$ and thy are successful models of their countries.

It should be a 'must have plan' for IMBs to survive and grow in the region. Otherwise, people may give them little importance and may not consider them different from CMBs.

\section{Conclusion}

After extensive research, we can conclude that the general living standard of people of Ghotki is not up to the mark and the Govt. \& NGos, so far, have been partially managing basic needs of the people. Thus, the demand of Islamic Microfinance in District Ghotki is very high and it is high time for Islamic microfinance service providers to establish their services in the area. The role of the state bank of Pakistan is also very important in this regard, and it should consider the need of Shariah compliant Microfinance services in the region and demand IMBs to open their branches here.

\section{Bibliography}

Akhuwat is Pakistan's largest NGO who has been providing interest free services to thousands of underprivileged people for a decade. Data available at: http://www.akhuwat.org.pk/philosophy/. Retrieved on July 6, 2018.

Amanah Ikhtiar is famous Malaysian microfinance bank. Data Available at: www.aim.gov.my/socialwork. Retrieved on June 26, 2018

Amjad and Shazia, The journal "Stanford Social Innovation Review" published an article on March 19, 2018 with the title "Philanthropy in Pakistan", written by Shazia Muhammad Amjad and Muhammad Ali. Retrieved from the website: [https://ssir.org/articles/entry/philanthropy_in_pakistan]

BBC, Urdu. A research article published on bbcurdu website on June $29^{\text {th }}, 2018$. Data retrieved on $30^{\text {th }}$ June, 2018 from the website: https://www.bbc.com/urdu/resources/idtsh/schools_pakistan.

Ben Rogaly, Susan Johnson have also discussed key aspects on the topic in their book: Microfinance and Poverty Reduction, Oxfam, UK, 1999.

Benazir income support program started in 2008. Data available at: http://bisp.gov.pk/. Retrieved on July 4, 2018

${ }^{22}$ Amanah Ikhtiar is famous Malaysian microfinance bank. Data Available at: www.aim.gov.my/socialwork. Retrieved on June 26, 2018

${ }^{23}$ Akhuwat is Pakistan's largest NGO who has been providing interest free services to thousands of underprivileged people for a decade. Data available at: http://www.akhuwat.org.pk/philosophy/. Retrieved on July 6,2018 
Cedric Lutzenkirchen, Article "Microfinance in evolution", published by Deutsche Bank Research Marketing, Frankfurt, Germany on September 13, 2012 Retrieved from website: www.esocialsciences.org/Download/Download.asp

Census, Pakistan, Information as per record of census 2017 provided by Pakistan Bureau of Statistics. Available at:

http://www.pbs.gov.pk/sites/default/files/PAKISTAN\%20TEHSIL\%20WISE\%20FOR\% 20WEB\%20CENSUS_2017.pdf. Retrieved on July 2, 2018.

Education, Sindh. Retrieved (on $26^{\text {th }}$ June, 2018) statistics of educational institutions in district Ghotki from following website: [http://www.schoolinglog.com/School-CollegeSystems-By/Primary-School/Government-Of-Sindh/Sindh/Ghotki.

Grameen bank is well-known because of its unprecedented social work in underprivileged communities. Available at: http://www.grameen.com/16-decisions/. Retrieved on July 5, 2018.

Haughton \& Khandker, (2009), Handbook on Poverty and Inequality, The World Bank, Washington Dc. USA P. 2-4

Microfinance, Active members in Pakistan. The website claims that by 2016, there were around 4 million active borrowers using the services of CMFi: Available at: http://www.microfinanceconnect.info/industrynews. Retrieved on 6 July, 2018

Microfinance, history. The state bank of bank of Pakistan presented brief history of Microfinance in Pakistan in $2^{\text {nd }}$ quarterly report of financial year 2006: http://www.sbp.org.pk/reports/quarterly/fy06/second/microfinance.pdf. Retrieved on Jun25, 2018.

National Assembly of Pakistan, Question Answer Session 34, Available at: [http://www.na.gov.pk/uploads/documents/questions/1470057800_189.pdf.]. Retrieved on July 3, 2018

National Assembly of Pakistan, Question Answer Session 34, retrieved from: [http://www.na.gov.pk/uploads/documents/questions/1470057800_189.pdf, P.18

National Rural Support Program Microfinance Bank. Relevant data available at: [https://www.nrspbank.com/introduction.php.]. Retrieved on July 1, 2018

October 2009 on cgap.org. Available at: http://www.cgap.org/blog/does-microcreditreally-help-poor-people. Retrieved on June 28, 2018.

Rosenberg, Richard, article "Does Microfinance really help Poor People"?

Sachs, Jaffery D.(2005)The End of Poverty, economic possibilities for our time, New York: The penguin press. P. 3-5 
Soussi, Alejandro Artiach, Article "Why are the interest rates of Microfinance institutions higher than those of banks?", September 2017.Available on: https://www.munplanet.com/articles/microfinance/why-are-the-interest-rates-ofmicrofinance-institutions-higher-than-those-of-banks. Retrieved on June 29vxz, 2018

Sundaresan, Suresh has also discussed key aspects of conventional microfinance in his book: Microfinance: Emerging Trends and Challenges, Edward Elgar Publishing Limited, UK, 2008. Available on www.aim.gov.my/introduction.php. Retrieved on June 27,2018

The interview of Mr. Abid Qamar, Chief spokesman, SBP is available at: https://www.thenews.com.pk/print/50776-sbp-grants-islamic-banking-licence-tomicrofinance-bank. Retrieved on July 3, 2018

Younus, Muhammad,(2007), Creating a world without poverty, New York: Public Affairs, PP 77-80

Younus, Muhammad, was given noble prize in 2006. Retrieved from the website: https://www.nobelprize.org/nobel_prizes/peace/laureates/2006/ Available at: http://www.grameen.com/method-of-action/. Retrieved on July 5, 2018 